\title{
STUDY RESULTS OF THE PRESENCE OF Culicoides spp. IN SERBIA DURING 2017
}

Ivan Pavlović ${ }^{*}$, Slobodan Stanojević ${ }^{1}$, Ljubiša Veljović1, Jelena MaksimovićZorić ${ }^{1}$, Oliver Radanović ${ }^{1}$, Budimir Plavšić ${ }^{2}$, Boban Đuriće, Saša Ostojić ${ }^{2}$

${ }^{1}$ Scientific Veterinary Institute of Serbia, Belgrade, Republic of Serbia

${ }^{2}$ Ministry of Agriculture, Forestry and Water Management, Veterinary Directorate, Belgrade, Republic of Serbia

\section{Abstract}

During 2017, 784 insect samples were examined and the presence of Culicoides spp. was established in $25.51 \%$ of samples. Earlier research has found that the dominant population of Culicoides spp in Serbia belongs to Obsoletus complexes, established in $60.05 \%$ of analyzed samples. Out of the entire insect population analyzed, males were found in $22.84 \%$, unpigmented (young) females in $67.97 \%$, females who took blood in $7.39 \%$, whereas $1.35 \%$ were gravid females. Culicoides spp. from the Pulicaris complex was established in $38.85 \%$ of examined samples. Males were found in $18.91 \%$, unpigmented (young) females in $71.72 \%$, females who took blood in $9.09 \%$, and $1.11 \%$ were gravid females. Other types of culicoids have been established in less than $10 \%$ of the examined samples. During examination, the most prevalent species were Culicoides obsoletus, C. picturalis, C. lupicaris, C. scoticus and C. fascipennis.

Keywords: Culicoides spp., epizootiology, Serbia

\footnotetext{
${ }^{1}$ Corresponding author: dripavlovic58@gmail.com
} 


\title{
REZULTATI ISPITIVANJA PRISUSTVA Culicoudes spp. U SRBIJI TOKOM 2017. GODINE
}

\author{
Ivan Pavlovićc ${ }^{*}$, Slobodan Stanojević ${ }^{1}$, Ljubiša Veljovićc ${ }^{1}$ Jelena Maksimović- \\ Zorić ${ }^{1}$, Oliver Radanović ${ }^{1}$, Budimir Plavšić ${ }^{2}$, Boban Đurić ${ }^{2}$, Saša Ostojić ${ }^{2}$ \\ ${ }^{1}$ Naučni institut za veterinarstvo Srbije, Beograd, Republika Srbija \\ ${ }^{2}$ Ministarstvo poljoprivrede, šumarstva i vodoprivrede, \\ Uprava za veterinu, Beograd, Republika Srbija
}

\section{Kratak sadržaj}

Tokom 2017. pregledano je 784 uzorka insekata a prisustvo Culicoides spp. je ustanovljeno u 25,51\%. Dosadašnja istraživanja potvrdila su da je u Srbiji dominantna populacija Culicoides spp. iz Obsoletus kompleksa koji su ustanovljeni u 60,05\% analiziranih uzoraka. Mužjaci su nađeni u 22.84\% ispitanih uzoraka insekata, nepigmentisane (mlade) ženke u 67,97\%, ženke koje su uzele krv u 7,39\%, a 1,35\% su bile gravidne ženke. Culicoides spp. iz Pulicaris kompleksa ustanovljeni su $38.85 \%$. Mužjaci su nađeni u $18.91 \%$, nepigmentisane (mlade) ženke u 71,72\%, ženke koje su uzele krv u 9,09\%, a $1,11 \%$ su bile gravidne ženke. Ostale vrste kulikoida su ustanovljene u manje od $10 \%$ pregledanih uzoraka. Tokom ovih pregleda dominantne su bile sledeće vrste: Culicoides obsoletus, C. picturalis, C. lupicaris, C. scoticus i C. fascipennis.

Ključne reči: Culicoides spp., epizootiologija, Srbija

\section{INTRODUCTION}

Entomofauna of Serbia is rich and diverse. Among this abundance of arthropods and insects, some species were not a topic of interest of the experts since they did not stand out as potential vectors, or simply did not come to the point that experts were dealing with them (Krunić, 1986). This was the case with the family of Ceratopogonidae, which belongs to the family Culicodina. Insects of the genus Culicoides spp. have not been studied in Serbia, so there were contradictory opinions about their persistence in our area (Pavlović et al., 2002). Only with the outbreak of bluetongue disease in 2006, the study of this kind of insects became important and the first research was started in order to determine the presence and extent of these insects (Pavlović et al., 2002). The 
research carried out during 2006-2007 confirmed their presence throughout the territory of Serbia. Research in the period 2011-2012 was focused on the study of Cullicoides species that are present in Serbia (Pavlović et al., 2009). Finally, in 2014, the re-emergence of bluetongue disease emphasized the need for continuous control of the presence of these insects (Maksimović Zorić et al., 2016). Since then, continuous annual monitoring of these insects has been conducted that gave an insight into their seasonal dynamics as well as the most dominant species (Pavlović et al., 2014; 2016a; 2016b; 2017).

\section{MATERIAL AND METHODS}

Based on the instructions of Veterinary Directorate on performing entomological and virological tests for the monitoring and surveillance of bluetongue disease (BTD) in the Republic of Serbia No. 323323-02-10787/2016-05 dated $12 / 02 / 2016$ in the period from $01 / 01 / 2017$ to $31 / 12 / 2017$ entomological tests were carried out in order to control bluetongue disease.

In that period, a total of 784 entomological check-ups were made. Culicoides spp. samples were collected from all epizootic areas in Serbia. Determination of Culicoides spp insects was made by morphometric method recommended by the Italian National Reference Centre for Exotic Diseases (National Reference Centre for the study of Exotic Animal Diseases (CESME)) and OIE Reference Laboratory for Bluetongue Istituto Sperimentale Zooprofilattico dell'Abruzzo e del Molise "G. Caporale" (IZSAM) from Teramo, Italy. Species definition of Culicoides spp. has traditionally been based on the morphology of adult insects (Goffredo and Meiswinkel, 2004). Adult individuals of $\mathrm{Cu}$ licoides spp. are notable for their characteristic wing pigmentation pattern and distribution of wing microtrichia, which in certain species can be used as the principle diagnostic feature. In practice, however, the requirement is that specimens should be slide mounted, image-captured, measured and analysed, which is time consuming and therefore the use of morphometries for identification purposes in high-throughput systems such as surveillance programs is recommended (Weeks et al., 1999; Mathieu et al., 2012).

\section{RESULTS}

Of the total number of insect samples, the presence of Culicoides spp. was established in $25.51 \%(200 / 784)$.

In the epizootic area of Belgrade, Culicoides spp. was found in $24.39 \%$ (10/41) samples, while in Central Serbia, Culicoides spp. was detected in 
Požarevac in 28.57\% (24/84) samples, Kraljevo in 45.75\% (70/153), Niš in $47.64 \%$ (81/170), Zaječar in $28.42 \%$ (27/95) and in Šabac in $78.84 \%(41 / 52)$ of tested samples. No presence of Culicoides spp. (0/0) was detected in the epizootic area of Jagodina.

In the Vojvodina Province, the presence of Culicoides spp was found in $38.46 \%(10 / 26)$ samples in Novi Sad, in Pančevo in 44.18\% (19/43), Subotica in 59.25\% (32/54) and in Sombor in 40.90\% (9/22) of tested samples. We did not detect the presence of Culicoides spp. in the epizootic area of Zrenjanin (Central Banat District) (0/0).

Earlier research has found that the dominant population of Culicoides spp in Serbia belongs to Obsoletus complexes, which was established in $60.05 \%$ of samples. Males were found in $22.84 \%$ samples, non-pigmented (young) females in $67.97 \%$, females taking the blood at $7.39 \%$, while $1.35 \%$ were pregnant females.

Culicoides spp. from Pulicaris complexes were found in $38.85 \%$ samples. Among tested samples, males were found in $18.91 \%$ samples, non-pigmented (young) females in $71.72 \%$, females who took blood in $9.09 \%$ and $1.11 \%$ were pregnant females.

Other types of Culicoides are set up in less than $10 \%$ of the examined samples.

\section{DISCUSION}

During the previous examinations, 22 species of Culicoides were found and the following species were dominant in 2017: Culicoides obsoletus, C. picturalis, C. lupicaris, C. scoticus and C. fascipennis. As compared with the period 20152016, a change in a faunistic sense since the dominant species in the previous period included C. obsoletus, C. pulicaris, C. parrots and C. nubeculosus (Pavlović et al., 2017).

Increasing spread of Culicides, the emergence of new genera in some areas and the large number of these insects is a consequence of climate change. In the last century, the mean air temperature in the world increased by $0.5{ }^{\circ} \mathrm{C}$ (Blackwell, 2001; Wilson and Mellor, 2008). The temperature and relative humidity of the air have the most important influence on the short-term fluctuations of Culicoides (sudden increase in number) and then on their long-term spread. World-wide studies have established that majority of these insects do not appear when the average air temperature is below $13{ }^{\circ} \mathrm{C}$ and above $35{ }^{\circ} \mathrm{C}$ (Mehlhorn et al., 2007; Purse et al., 2015; Pavlović et al., 2016b). This is also reflected on the biodiversity of present species in certain regions. Thus, C. imicola appeared and soon it was the dominant species of eastern Spain, southern 
France, northern Italy, northern and southern Greece, the coastal part of Albania, Montenegro, Bosnia and Herzegovina and Croatia (Patakakis et al., 2009; Omeragić et al., 2009; Bosnić, 2011). On the other hand, the Culicoides species from Obsoletus Complex and Pulicaris Complex dominate in the western Balkans (Serbia, Bulgaria, and Romania) (Ioniţă et al., 2009; Bobeva et al., 2013; Pavlović et al., 2016a).

Culicoides's seasonal dynamic is directly correlated with temperature and humidity. Culicoides from both groups - Obsoletus and Pulicaris complex, were reaching maximum abundance in spring and autumn, which is normal for this species (Conte et al., 2007; Pavlović et al., 2016a). High temperatures favour their development, while very high temperatures can reduce the survival of adult insects. This correlation was observed during the monitoring of the seasonal dynamic of Culicoides in Serbia in the period 2006-2007, 20112012 and from 2015 until today (Pavlović et al., 2017). The average season for the appearance of these insects is from March to October, depending on the area being tested. Seasonal dynamics of the presence of Culicoides spp. were monitored during one year.

During January, February and November 2017, Culicoides spp. were not found in any of the tested samples. During March, their prevalence was $1.58 \%$ (1/63), during April 31.73\% (27/85), in May it was 49.29\% (35/71), June 66.66\% (60/90), July 77.89\% (74/95), August 66.21\% (49/74), September 66.66\% (35/71), October 49.29\% (35/71) and December 3.44\% (2/58).

Culicoides are also subjected to molecular assays (RT-PCR) to analyze the presence of blue tongue viral genome. The genome of blue tongue disease virus was identified in one sample from the territory of the Mionica municipality in September 2016, which is an expected finding considering the outbreak of this disease just in the month of September.

\section{CONCLUSION}

During 2017, a total of 784 entomological check-ups were made. Of the total number of insect samples, the presence of Culicoides spp. was established in $25.51 \%(200 / 784)$. During the examination period, there was a change in view of dominant species of Culicoides species. In our examination dated 2017, the dominant species were Culicoides obsoletus, C. picturalis, C. lupicaris, C. scoticus and C. fascipennis. As compared with the period 2015-2016 there was a change in the faunistic sense, that is, the dominant species in the previous period were C. obsoletus, C. pulicaris, C. parrots and C. nubeculosus. This was influenced by microclimatic and other biotic factors. 


\section{REFERENCES}

1. Blackwell, A.: Recent advances on the ecology and behaviour of Culicoides spp in Scotland and the prospects for control. Veterinary Bulletin, 71, 1, 1R-8R, 2001.

2. Bobeva A, Zehtindjiev P, Bensch S, Radrova J.: A survey of biting midges of the genus Culicoides Latreille, 1809 (Diptera: Ceratopogonidae) in NE Bulgaria, with respect to transmission of avian haemosporidians. Acta $\mathrm{Pa}$ rasitologica, 58, 4, 585-91, 2013.

3. Bosnić S.: Entomološka istraživanja insekata roda Culicoides vektora virusa bolesti plavog jezika u Hrvatskoj. Doktorska disertacija, Veterinarski fakultet Zagreb, 2011.

4. Conte A., Goffredo M., Ippoliti C., Meiswinkel R.: Influence of biotic and abiotic factors on the distribution and abundance of Culicoides imicola and the Obsoletus Complex in Italy. Veterinary Parasitology, 150, 333-44, 2007.

5. Goffredo M., Meiswinkel R.: Entomological surveillance of bluetongue in Italy: methods of capture, catch analysis and identification of Culicoides biting midges. Veterinaria Italiana, 40, 3, 260-65, 2004.

6. Ioniţă M, Mitrea I, Buzatu M, Dascălu L.A.I. Seasonal dynamics of haematophag arthropod populations (ticks and Culicoides spp.) - vectors of pathogens in animals and humans, in different areas of Romania. Lucrări Ştiinţice Medicină Veterinară, 52, 629-36, 2009.

7. Krunić M.: Zoologija invertebrata, II deo. Beograd: Naučna knjiga, 1986.

8. Maksimović Zorić J., Milićević V., Veljović Lj., Pavlović I., Radosavljević V., Valčić M., Glišić M.: Bluetongue disease - epizootiology situation in Serbia in 2015, diagnosis and differential diagnosis. Archives of Veterinary Medicine, 9, 1, 13-22, 2016.

9. Mathieu B, Cêtre-Sossah C, Garros C, Chavernac D, Balenghien T, Carpenter S, et al.: Development and validation of IIKC: an interactive identification key for Culicoides (Diptera: Ceratopogonidae) females from the Western Palaearctic region. Parasites and Vectors, 5, 137-139, 2012.

10. Mehlhorn H, Walldorf V, Klimpel S, Jahn B, Jaeger F, Eschweiler J, Hoffmann B, Beer M.: First occurrence of Culicoides obsoletus - transmitted bluetongue virus epidemic in Central Europa. Parasitology Research, 101, 219-228, 2007.

11. Omeragic J., Vejzagic N., Zuko A., Jažić A.: Culicoides obsoletus (Diptera: Ceratopogonidae) in Bosnia and Herzegovina-first report. Parasitology research, 105, 2, 563-5, 2009.

12. Patakakis M.J., Papazahariadou M., Wilson A., Mellor P.S., Frydas S., Papadopoulos O.: Distribution of Culicoides in Greece. Journal of Vector Ecology, 34, 2, 234-251, 2009. 
13. Pavlović I., Jermolenko G., Milošević B., Stankov S.: Epizootiološka uloga Culicoides u širenju bolesti plavog jezika i drugih oboljenja Zbornik radova IV jugoslovenskih epizootioloških dana sa međunarodnim učešćem, Mataruška Banja, 2002, 105-106.

14. Pavlović I., Rajković M., Kolarević M.: Kontrola kulikoida - determinacija i suzbijanje. Zbornik radova XX Savetovanja dezinfekcija, dezinsekcija i deratizacija u zaštiti zdravlja životinja i ljudi sa međunarodnim učešćem, Divčibare, 2009, 89-92.

15. Pavlović I., Stanojević S., Rajković M., Šekler M., Plavšić B.: Dosadašnja istraživanja Culicolides (Insecta: Ceratopogonidae) u Srbiji. Zbornik kratkih sadržaja XVI epizootiološki dani Srbije, Zrenjanin, 2014, 85-87.

16. Pavlović I.: Epidemiology of Culicoides species in Serbia - lessons learned from the national monitoring program after bluetongue outbreak. Textbook of SCOPES International Partnership "Arbovirus Monitoring, Surveillance and Research-capacity building on mosquitoes and biting midges (AMSAR)" Summer School in Stara Planina and Belgrade, Serbia: "Morphological identification and PCR screening of vectors transmitting Bluetongue, Schmallenberg and West Nile virus", 2016a, lecture 8, 1-7.

17. Pavlović I., Bojkovski J., Silaghi C., Veronesi E., Vasić A., Simeunovic P., Oslobanu L., Aniţa D.: Impact of environmental factors on the biodiversity of Culicoides (Insecta: Ceratopogonidae) in Serbia. Book of Abstracts of International Conference on Ecological Crisis: Technogenesis and Climate Change. Belgrade, Serbia, 2016b, 71-72.

18. Pavlović I., Veljović Lj., Milićević V., Maksimović Zorić J., Stanojević S., Radanović O., et al.: Seasonal dynamics of the presence of Culicoides spp. in Serbia in the period 2015-2016. Arhiv veterinarske medicine, 10, 1, 3-12, 2017.

19. Purse B.V., Carpenter S., Venter GJ, Bellis G, BA M.: Bionomics of Temperate and Tropical Culicoides Midges: Knowledge Gaps and Consequences for transmission of Culicoides - Borne Viruses. Annual Review of Entomo$\log y$, 60, 373-392, 2015.

20. Wilson A., Mellor P.: Bluetongue in Europe: vectors, epidemiology and climate change. Parasitology Research, 103, 1, 69-77, 2008.

21. Weeks P.J.D., O’Neill M.A., Gaston K.J., Gauld I.D.: Automating insect identification: exploring the limitations of a prototype system. Journal of Apply Entomology, 123, 1-8, 1999. 
